\title{
Al-Qur'ān: Memerangi Illiteracy, Mencipta Peradaban Ilmu Pengetahuan
}

\author{
Ali Romdhoni ${ }^{1}$
}

\begin{abstract}
This article would like to show that the Qur'an has influenced the development of Islamic civilization and sciences. In order to prove that, this article will tackle two questions, firstly when did the Arabic literacy tradition develop in Arab community, and secondly, which factors did influence the development of Islamic civilization.

This article argues against Ibn Khaldūn (d. $808 \mathrm{H}$ ), who claims that literacy depends on the economic development. According to the author of this article, this condition is not relevant with the Arab community, since the economi condition of the Arabs at the time was not prosperous. This article argues that piety, religiousity, and Muslim dedication to learn from the Qur'an which influence the development of Islamic civilization.
\end{abstract}

Keywords: al-Qur'ān, literacy, ummī.

\section{Pendahuluan}

Tradisi literasi ${ }^{2}$ Arab menempati posisi penting dalam proses penciptaan bangunan ilmu pengetahuan keislaman. Ia menjadi jembatan penghubung antara ajaran keislaman dengan peradaban (terutama khazanah intelektual) pra-Islam. Dalam hubungannya dengan al-Qur'ān, literasi Arab sangat berguna karena telah mendokumentasikan wahyu (al-Qur'ān) dalam bentuk teks tertulis sehingga bisa dikaji secara lebih komprehensif oleh generasi Islam pada masa

\footnotetext{
${ }^{1}$ Dosen STAI Mathali'ul Falah. Alamat: Jalan Raya Pati-Tayu Km. 20 Purworejo Margoyoso Pati Jateng. E-mail. aliromdhoni@yahoo.com.

${ }^{2}$ Literasi (literacy) secara harfiah bermakna baca-tulis, melek aksara, dan keberaksaraan. Literasi juga berarti kemampuan membaca dan menulis. Sementara dalam bahasa Arab literasi diterjemahkan dengan ma'rifah al-qirā'ah wa al-kitābah (معرفة القزاءة والكتابة). Dalam tulisan ini literasi dimaknai sebagai tradisi intelektualitas yang bisa mengangkat martabat satu bangsa dari golongan "awam" kepada bangsa terpelajar dan beradab. Out-put dari tradisi literasi adalah lahirnya peradaban ilmu pengetahuan. Baca Jean E. Spencer, "Literacy" dalam The Encyclopedia Americana International Edition, Vol. 17 (New York: Americana Corporation, 1972), 559. Lihat juga "Literacy" dalam Munir al-Ba'labakkī, al-Mawrid: Qāmūs Ingelizí-'Arabì (Beirut: Dār al-'Ilm lil Malāyin, 1977), 34.
} 
selanjutnya. ${ }^{3}$ Ia juga yang mengantarkan Islam dikenal di berbagai wilayah dunia Islam - mulai dari Arab, Spanyol, sampai di India - sebagai agama yang cinta ilmu pengetahuan. Bermula dari tradisi baca-tulis, kelak Islam menghasilkan beribu-ribu jilid buku ilmu pengetahuan dan mewariskan beragam bangunan peradaban yang agung, tak ternilai harganya. ${ }^{4}$ Karena itu, sangat tepat bila tradisi literasi Arab disebut sebagai cikal bakal lahirnya ilmu-ilmu keislaman sekaligus sebagai pintu gerbang menuju kejayaan Islam.

Anggapan seperti di atas juga dibenarkan Ibn Khaldūn (m. 808 H/ 1406 M). Menurut sosiolog muslim terbesar ini, melalui perantara tulisan (khatt; kitäbah) memungkinkan untuk mengakses informasi (tertulis) baik mengenai tradisi intelektual maupun sejarah bangsa-bangsa terdahulu dengan mudah. ${ }^{5}$ Sementara menurut Qatādah, kemampuan membaca dan menulis adalah karunia tertinggi yang dianugerahkan oleh Tuhan kepada manusia. Ia menjadi perantara untuk memahami sesuatu. Tanpa tradisi baca-tulis, agama (Islam) tidak akan pernah berjaya. ${ }^{6}$ Begitu juga J. Pedersen yang menyatakan bahwa tradisi bacatulis Arab merupakan roda penggerak peradaban (Islam). ${ }^{7}$ Fakta sejarah membuktikan peradaban Islam bergantung kepada tradisi baca-tulis baik dalam proses pertumbuhan maupun pelestariannya. ${ }^{8}$

Pendapat-pendapat di atas cukup beralasan, karena tanpa memiliki tradisi baca-tulis yang "mapan" generasi muslim awal tidak mungkin mampu mempelajari prestasi bangsa-bangsa lain di sekitarnya, untuk selanjutnya menciptakan peradaban baru yang lebih unggul dan bermanfaat. Peradaban Islam berkembang seiring dengan maraknya kesadaran masyarakat muslim untuk membaca sumber-sumber informasi dan ilmu pengetahuan yang bisa dijumpai, serta mendokumentasikan hasil temuan dalam bentuk catatan yang rapi. ${ }^{9}$ Seandainya kekayaan ilmu pengetahuan Islam tidak dibukukan, maka

${ }^{3}$ Al-Suyūṭi, al-Itqān fì 'Ulūm al-Qur'ān, juz 1 (Beirut: Dār al-Kutub al-'Ilmiyah, 2000), 116.

${ }^{4}$ Buku-buku yang ditulis para intelektual muslim kelak memberi penjelasan kepada dunia luas tentang wajah Islam yang damai dan cinta ilmu pengetahuan. Bandingkan dengan Philip K. Hitti, History of the Arabs (London: Macmillan Education, 1970), Tenth edition, 4.

${ }^{5}$ Ibn Khaldūn, Muqaddimah (Dār al-Fikr, t.th), 417.

${ }^{6} \mathrm{Al}-\mathrm{Qurṭub} \overline{\mathrm{i}}$, al-Jāmi ' li Aḥkām al-Qur'ān, Jilid 10 (Beirut: Dār al-Kutub al'Ilmiyyah, 1993), 81. Baca juga al-Ṭabarì, Jämi' al-Bayān fì Ta'wìl al-Qur'àn, cetakan pertama, juz 24 (Mu'assasah al-Risālah, 2000), 519.

${ }^{7}$ J. Pedersen, Fajar Intelektualisme Islam, terj. Alwiyah Abdurrahman, cetakan pertama (Bandung: Mizan, 1996), 110.

${ }^{8}$ F. Rosental, "Significant Uses of Arabic Writing" dalam R. Ettinghausen dan O. Kurz (ed), Four Essays on Art and Literature in Islam, Vol. 2 (Leiden: E. J. Brill, 1971), 60. Baca juga Ilham Khoiri R, al-Qur'ān dan Kaligrafi Arab (Jakarta: Logos, 1999), 3.

${ }^{9}$ M. Amin Abdullah, "Penerjemahan Karya Klasik" dalam Ensiklopedi Tematis Dunia Islam, Pemikiran dan Peradaban (Jakarta: Ichtiar Baru van Hoeve, 2002), 15-21. 
sedikit demi sedikit ia pasti akan hilang. Bila sudah demikian, prestasi-prestasi yang pernah dicapai Islam pun tidak akan dikenal orang-orang pada masa sekarang.

Masalahnya, sejak kapan tradisi literasi Arab mulai berkembang dan apa yang menyebabkan peradaban ilmu pengetahuan keislaman berkembang pesat?

\section{Sejarah Literasi di Lingkungan Masyarakat Arab}

Kalangan intelektual muslim bersilang pendapat mengenai dimulainya tradisi literasi atau baca-tulis di tengah-tengah masyarakat Arab. Pendapat pertama mengemukakan mayoritas penduduk bangsa Arab tidak mengenal tradisi baca-tulis, alias buta aksara. Baru pada masa awal Islam tradisi membaca dan menulis berkembang pesat di kalangan muslim Arab. Pendapat seperti ini dikatakan oleh al-Fārūqui, ${ }^{10}$ al-A'zami ${ }^{11}$ Hadi Ma'rifat, ${ }^{12}$ Bernard Lewis, ${ }^{13}$ Hasan Ibrahim Hasan, ${ }^{14}$ M. Quraish Shihab, ${ }^{15}$ Mustansir Mir, ${ }^{16}$ dan P.K. Hitti. ${ }^{17}$

${ }^{10}$ Isma'il R. al-Faruqi dan Lois Lamya' al-Faruqi, The Cultural Atlas of Islam (New York: Macmillan Publishing Company, 1986), 357.

${ }^{11}$ Al-A'zami, Sejarah Teks Al-Qur'ān, terj. Sohirin Solihin, dkk (Jakarta: Gema Insani Press, 2005), 151-154.

${ }^{12}$ Muhammad Hadi Ma'rifat, Sejarah Al-Qur'ān (Jakarta: Al-Huda, 2007), $177-$ 185.

${ }^{13}$ Menurut Lewis, peradaban intelektual Islam adalah hasil akhir dari pengaruh alQur'ān. Lewis, The Arabs in History, cet.1 ${ }^{\text {st }}$ (New York: Harper Torchbooks, 1960), 136.

${ }^{14}$ Hasan menjelaskan, Nabi Muhammad s.a.w. adalah orang pertama yang menaruh perhatian serius terhadap pengajaran baca-tulis kepada masyarakat Arab. Berbagai upaya dia lakukan untuk mengentaskan masyarakat Arab dari keterpurukan akibat buta aksara. Hasan Ibrahim Hasan, Sejarah dan Kebudayaan Islam, terj. A. Bahauddin (Jakarta: Kalam Mulia, 2006), 108.

${ }^{15}$ Menurut M. Quraish Shihab, masyarakat Arab yang hidup pada masa turunnya al-Qur'ān adalah masyarakat yang tidak mengenal baca-tulis. Al-Qur'ān, demikian pula Nabi s.a.w., menganjurkan kepada kaum muslim untuk memperbanyak membaca dan mempelajari al-Qur'ān dan anjuran tersebut mendapat sambutan yang hangat. M. Quraish Shihab, Membumikan Al-Qur'ān: Fungsi dan Peran Wahyu dalam Kehidupan Masyarakat (Bandung: Mizan, 1999), 23-24.

${ }^{16}$ Menurut Mustansir Mir, budaya yang berkembang di masyarakat Arab adalah budaya yang bersifat lisan. Adapun yang menyebabkan terjadinya transformasi budaya dari pra-tulisan ke tulisan terutama adalah al-Qur'ān. Mustansir Mir, "The Qur'ān in Muslim Thought and Practice", dalam John L. Esposito (editor in chief), The Oxford Encyclopedia of the Modern Islamic World, Vol. 3 (New York: Oxford University Press, 1995), 394.

${ }^{17}$ Orang-orang Arab Utara mulai mengembangkan budaya baca-tulis menjelang masa Nabi s.a.w. Al-Qur'ān memainkan peran penting, di antaranya, sebagai pilar Islam dan otoritas tertinggi dalam persoalan-persoalan spiritual dan etika, menjadi buku ilmiah untuk memperoleh pendidikan. Al-Qur'an menjadi karya terbaik pertama yang menjadi model penciptaan berbagai karya prosa Arab. Hitti, History of the Arabs, 30-32 dan 127-129. 
Kelangkaan alat tulis dan ketidakmampuan baca-tulis mengantarkan bangsa Arab mengandalkan hafalan. ${ }^{18}$ Kemampuan menghafal, pada gilirannya, menjadi tolok ukur kecerdasan dan kemampuan ilmiah seseorang. Lebih parah lagi, seseorang yang bisa baca-tulis dianggap lemah daya ingat (hafalan)-nya (ḍa'if al-dhākirah) ${ }^{19}$ - karena itu kemampuan baca-tulis dianggap sebagai aib.

Karena kondisi ini, banyak peradaban masyarakat Arab yang tidak terdokumentasi secara teratur dalam bentuk catatan sejarah. ${ }^{20}$ Aktifitas perniagaan, sastra dan intelektual, jiwa kepahlawanan, dan keagamaan bangsa Arab hanya bisa dijumpai dalam wujud cerita-cerita yang masih diingat masyarakat itu sendiri, atau sisa-sisa berbagai peninggalan yang masih terpelihara hingga sekarang. Selebihnya, banyak yang dilupakan dan akhirnya hilang tidak terlacak. ${ }^{21}$ Pendeknya, tradisi baca dan tulis belum menjadi kesadaran masyarakat Arab kala itu. ${ }^{22}$

Al-Qur'ān (QS. al-Jumu'ah/62:2) sendiri menyebut bangsa Arab sebagai

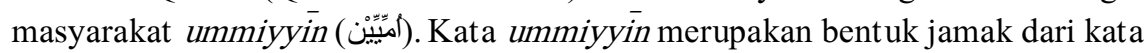
ummi, terambil dari kata umm yang arti harfiahnya adalah ibu. Yang dimaksud ummi di sini adalah seorang yang keadaannya sama dengan ketika dilahirkan oleh ibunya dalam hal kemampuan membaca dan menulis. ${ }^{23}$ Selain al-Qur'ān, hadis juga membenarkan bahwa masyarakat yang hidup pada masa Nabi s.a.w. adalah orang-orang ummi, yang tidak pandai menulis dan tidak bisa berhitung:

${ }^{18}$ Pada saat al-Qur'ān diturunkan bangsa Arab berada dalam martabat yang begitu tinggi dan sempurna daya ingatnya. Mereka bahkan banyak yang hafal ratusan ribu syair, dan mengetahui silsilah serta nasab (keturunan)-nya. Lihat al-Zarqāni, Manāhil al-'Irfän fì 'Ulūm al-Qur'ān, jilid 1 (Beirut: Dār al-Kutub al-'Ilmiyah, 1996), 240. Hal ini bertentangan dengan hasil riset lapangan, yang membuktikan dalam masyarakat niraksara (buta huruf) sangat sulit terjadi penghafalan karya yang panjang. Artinya, masyarakat yang tidak mengenal tulisan tidak mungkin bisa mengulang secara persis teks-teks yang telah dihafalkan, karena pada orang-orang yang tidak mengenal tulisan tidak terjadi sistem memorisasi otak (ingatan). Baca A. Teeuw, Indonesia: Antara Kelisanan dan Keberaksaraan (Jakarta: Pustaka Jaya, 1994), 4-5.

${ }^{19}$ Kebalikan da 'íf al-dhākirah adalah qawiyy al-dhākirah. Lihat Mannā' Khalìil Qatțān, Mabāhith fí 'Ulūm al-Qur'ān (Mekah: Maktabah al-Ma'ārif, 1988), 119. Baca juga Ali Romdhoni, “Al-Qur'ān dan Masyarakat Pembaca”, Surat Kabar Mahasiswa Amanat, IAIN Walisongo Semarang (109 Agustus-September 2007), 12.

${ }^{20} \mathrm{Hitti}$, History of the Arabs, 87.

${ }^{21}$ Khafaji menyebutkan, jenis prosa jahili sangat banyak. Karya sastra Arab jenis ini merekam jejak hampir semua peristiwa penting yang dialami masyarakat itu. Namun karena tidak ada upaya untuk mengkodifikasi-yang disebabkan mereka tidak bisa membaca dan menulis - akhirnya karya sastra ini banyak yang hilang. Hal ini berbeda dengan syair, karya sastra jenis ini mudah dihafal karena terkait dengan batasan-batasan wazan (musikalitas) dan qāfiyah (sajak). Baca Muhammad 'Abd al-Mun'im Khafāji, alShi 'r al-Jāhilì (Beirut: Dār al-Kitāo,1973), 136.

${ }^{22}$ Hasan, Sejarah dan Kebudayaan Islam, 108.

${ }^{23}$ M. Quraish Shihab, Mukjizat Al-Qur'ān (Bandung: Mizan, 1998), 71. 
Innā ummah ummiyyah, lā naktub wa la nậsub, al-shahr hākadhā, hākadhā, wa hākadhā (artinya, Kami adalah umat yang ummi, yang tidak pandai menulis, tidak juga pandai berhitung. Bulan begini, begini, dan begini). ${ }^{24}$

Selanjutnya, tradisi literasi Arab mulai berkembang bersamaan dengan lahirnya doktrin keislaman yang terkandung dalam al-Qur'ān (QS. al'Alaq/96:1-5) yang memerintahkan belajar membaca dan menulis. ${ }^{25}$ Nabi s.a.w. adalah orang pertama yang menaruh perhatian serius terhadap pengajaran bacatulis kepada masyarakat Arab. ${ }^{26}$ Dia terus memotivasi kaum muslim agar belajar baca-tulis. ${ }^{27}$ Ibarat gayung bersambut, motivasi Nabi s.a.w. disambut hangat oleh umat Islam. ${ }^{28}$ Karena itu, orang-orang yang belajar menulis pada saat itu semakin banyak.

Ini sedikit berbeda dengan pendapat Hadi Ma'rifat. Menurut dia, orangorang Arab Hijaz di masa lampau tidak bisa baca-tulis. Mereka baru mengetahui ilmu baca-tulis sejak mendekati munculnya Islam. Yang membuat bangsa ini tidak butuh ilmu baca-tulis adalah kehidupan badui-yang selalu menghabiskan waktu dalam perjalanan, mengembara, berperang dan merampok. Aktifitas yang demikian menghalangi orang-orang ini untuk berfikir tentang seni, termasuk seni baca-tulis. Namun demikian, pada masa-masa berikutnya, di antara mereka ada yang tertarik dan mau belajar baca-tulis. Adapun yang membuat budaya literasi berkembang dalam masyarakat Arab Hijaz adalah kontak budaya yang terjadi dalam perdagangan. Sebagian dari orang-orang Arab Hijaz ini melakukan perjalanan ke Syam dan Irak untuk tujuan dagang, lambat laun mereka

${ }^{24}$ al-Bukhārì, al-Jāmi ' al-Sahịh al-Mukhtașar, cetakan ketiga, juz 2 (Beirut: Dār Ibn Kathīr al-Yamāmah, 1987), 675 , nomor hadis 1814. Sumber lain mengatakan, umm $\bar{i}$ pada zaman Nabi s.a.w. merujuk pada orang-orang yang bukan Yahudi atau Nasrani. Pendapat ini didasarkan pada al-Qur'ān (QS. Ali Imrān/3:20) yang menggunakan istilah ummi secara khas dalam pengertian orang yang tidak termasuk kalangan Ahlulkitab (Yahudi dan Nasrani). Ayat itu mengatakan: ....... (artinya, "...Dan katakanlah kepada orang-orang yang telah diberi Alkitab dan orang-orang yang ummi...”). Karena itu, jelaslah bahwa ummi berarti bukan-Yahudi dan bukan-Nasrani. Ayat itu menunjukkan lebih lanjut bahwa ummi tidak berarti buta huruf, karena bila demikian maka implikasinya adalah bahwa semua orang Yahudi dan Nasrani saat itu adalah melek huruf, yang tentu saja tidak benar. Ayat lain yang juga menjelaskan bahwa kata ummi merujuk pada orang yang di luar Ahlulkitab (Yahudi dan Nasrani) adalah QS. Ali Imran/3:75, yang dalam ayat itu Ahlulkitab mengatakan:

(artinya, “...Tidak ada dosa bagi kami terhadap orangorang ummi....". Lihat Faruq Sherif, al-Qur'ān Menurut al-Qur'ān, terj. M. H. Assagaf dan Nur Hidayah (Jakarta: PT. Serambi Ilmu Semesta, 2001), 56. Baca juga ulasan Shaḥrūr tentang makna kata ummī dalam Muhammad Shaḥrur, al-Kitāb wa al-Qur'ān, Qirà’ah Mu'āsirah (Kairo: Sīnā li al-Nashr, 1992), 139.

${ }^{25}$ Shihab, Membumikan Al-Qur'ān, 23.

${ }^{26}$ Hasan, Sejarah dan Kebudayaan Islam, 108.

${ }^{27}$ Ma'rifat, Sejarah Al-Qur'ān, 178.

${ }^{28}$ Shihab, Membumikan Al-Qur'ān, 23. 
bersentuhan dan terpengaruh budaya masyarakat yang sudah maju dan beradab. Mereka kemudian belajar etika dan ilmu baca-tulis kepada orang-orang Syam dan Irak. $^{29}$

Pendapat kedua mengatakan masyarakat Arab sudah mengenal budaya baca-tulis selama berabad-abad jauh sebelum datangnya Islam. Kesimpulan ini didasarkan pada temuan sejumlah prasasti dalam bahasa Arab selatan yang bertanggal jauh sebelum era Kristen. Beberapa prasasti juga ditemukan di daerah barat Laut Arab dalam abjad Nabatean, ${ }^{30}$ Lihyanik, $^{31}$ dan Thamudik. ${ }^{32}$ Konon, benda-benda kuno ini dibuat pada abad-abad sebelum kelahiran Nabi Muhammad s.a.w. Penemuan lain yang juga menunjukkan adanya peradaban bahasa Arab klasik dan naskah-naskah bahasa Arab adalah tiga sketsa kasar yang menempel pada tembok suatu kuil di Siria, yang diyakini dibuat pada abad ketiga. $^{33}$

Kelompok ini juga mendasarkan argumennya pada kenyataan bahwa di Jazirah Arab terdapat Mekah yang masyhur sebagai kota dagang. Kota ini sudah menjadi pusat perniagaan yang sangat makmur bagi masyarakat perkotaan Arab sejak sebelum kelahiran Islam. ${ }^{34}$ Mekah bahkan menjadi kota transit para pedagang yang bolak-balik melintas dari Yaman, Yathrib (Madinah), Palestina, Siria, dan sebelah barat menuju Laut Merah dan Jeddah. ${ }^{35}$ Ketika Islam lahir, legenda kemasyhuran aktifitas dagang masyarakat Arab (Quraisy) yang secara teratur mengadakan perjalanan dua kali pada setiap tahunnya - di musim dingin ke Yaman dan di musim panas ke Syam-ter-cover dalam al-Qur'ān (QS. Quraisy/106:1-4). Logikanya, masih menurut kelompok kedua, tradisi baca-tulis tentu sudah menjadi kebutuhan kaum pedagang, lebih-lebih di kawasan perkotaan. Jadi, sangat tidak mungkin masyarakat Arab (Mekah dan sekitarnya) tidak mengenal baca-tulis. Di sisi lain, al-Qur'ān banyak berbicara mengenai fungsi tulisan. Al-Qur'ān, misalnya, menentukan bahwa transaksi utang-piutang yang dilakukan seorang muslim harus dicatat (QS. al-Baqarah/2: 282). Ini bisa

${ }^{29}$ Ma'rifat, Sejarah Al-Qur'ān, 177-185.

${ }^{30}$ Nabatean berasal dari nama satu kerajaan di semenanjung Arab. Bangsa Nabatean merupakan cikal bakal kaum Thamud, kaum Nabi Shaleh as. Kaum yang dianugrahi kemahiran dalam memahat dan mengukir bebatuan menjadi rumah dan istana-istana raksasa. Kawasan Nabatean membentang luas mulai dari Madain Shaleh di Madinah, Arab Saudi sampai kawasan Petra di Jordan dan Damshiq di Syiria.

${ }^{31}$ Lihyanik berasal dari kata lihyan, yaitu nama salah satu kabilah (bani) pada masa Nabi s.a.w.

${ }^{32}$ Thamudik berasal dari kata Thamud, yaitu nama kaum Nabi Shaleh a.s.

${ }^{33}$ Taufik Adnan Amal, Rekonstruksi Sejarah Al-Qur'ān (Jakarta: Pustaka Alvabet, 2005), 145.

${ }^{34} \mathrm{Hitti}$, History of the Arabs, 104.

${ }^{35}$ Baca Muh. Zuhri, Potret Keteladanan Kiprah Politik Muhammad Rasulullah (Yogyakarta: LESFI, 2004), 15. 
dimaknai bahwa audien al-Qur'ān adalah masyarakat yang mengerti (berbudaya) baca-tulis.

Di antara yang mendukung pendapat ini adalah Taufik Adnan Amal. Menurutnya, sejatinya masyarakat Arab sudah berbudaya baca-tulis selama berabad-abad jauh sebelum datangnya Islam. Selain mendasarkan kesimpulan ini prasasti dalam bahasa Arab selatan, dia juga mengaitkan dengan perdagangan sebagai suatu yang identik dengan tradisi baca-tulis. ${ }^{36}$ Anggapan ini tentu sulit dibuktikan. Karena pada praktiknya, aktifitas perdagangan orangorang Arab yang melegenda dan berusia puluhan bahkan ratusan tahun itu tidak merubah pola hidup mereka kecuali sedikit sekali. Hal yang membuat kondisi hidup mereka lebih baik, termasuk dalam hal tradisi baca-tulis adalah turunnya al-Qur'ān. ${ }^{37}$

Sementara menurut penulis Muqaddimah Ibn Khaldūn, kemampuan menulis merupakan keahlian (ketrampilan), yang proses transformasinya-dari potensi (al-quwwah) kepada aktualisasi diri (al-fi's)-berlangsung melalui pembelajaran (al-ta'lim). Karena keahlian, perkembangan dan kelestarian tradisi tulis menulis mengandaikan adanya komunitas sosial, lingkungan yang kondusif, peradaban dan kompetisi yang mewadahi dan menjamin keberlangungan tradisi itu. Karena itu, biasanya tradisi tulis menulis tumbuh pada komunitas yang sudah mapan-di pusat kota dan pemerintahan. Sebaliknya, pada masyarakat Badui sangat jarang dijumpai ada orang yang bisa membaca dan menulis, kecuali sangat sedikit. Itupun dengan kemampuan yang sangat terbatas. ${ }^{38}$

Dari pemikiran Ibn Khaldūn ini bisa diambil pemahaman, bahwa dalam kasus tradisi literasi Arab, pada masa-masa sebelum turunnya al-Qur'ān masyarakat Hijāz belum punya sarana pendukung bagi pertumbuhan dan kelestarian peradaban literasi, yaitu: komunitas sosial, lingkungan yang kondusif, peradaban dan kompetisi yang mewadahi dan menjamin keberlangungan tradisi literasi. Maka, wajar apabila saat itu tradisi literasi sulit berkembang di Hijāz.

\section{Penulisan al-Qur'ān: Titik Awal Kodifikasi Ilmu Keislaman}

Terlepas dari perbedaan pendapat tentang kapan dimulainya tradisi bacatulis di tengah-tengah masyarakat Arab serta apa yang membuat literasi Arab berkembang pesat, sejarah mencatat, literasi Arab menemukan momentumnya bersamaan dengan turunnya unit wahyu pertama (QS. al-'Alaq/96:1-5), yaitu

\footnotetext{
${ }^{36}$ Amal, Rekonstruksi Sejarah Al-Qur'ān, 145.

${ }^{37}$ Bandingkan dengan Shihab, Mukjizat Al-Qur'ān, 73. Baca juga Hitti, History of The Arabs, 87.

${ }^{38}$ Ibn Khaldūn, Muqaddimah, 417.
} 
perintah untuk belajar membaca dan menulis. Di sini, selain motivasi untuk menjalankan perintah al-Qur'ān, umat muslim juga berkepentingan untuk merekam kata-kata al-Qur'ān. Sejarah pun mencatat, tulisan Arab diperankan untuk mengabadikan kata-kata al-Qur'ān dalam orisinalitasnya. ${ }^{39}$ Di Mekah, Nabi menyeleksi orang-orang yang pandai baca-tulis. Sahabat-sahabat penulis terbaik ini diperintahkan untuk mencatat berbagai macam urusan umat muslim, termasuk wahyu yang turun. ${ }^{40}$

Mereka yang didaulat Nabi untuk menulis wahyu adalah Abū Bakar,

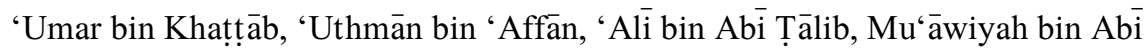
Sofyān, Zaid bin Thābit, Khālid bin Walìd, 'Ubai bin Ka'ab, dan Thābit bin Qais. ${ }^{41}$ Al-Zarkashi dalam al-Burhān mengutip pernyataan Anas r.a. yang diriwayatkan oleh Bukhari dan Muslim, Anas berkata: "Al-Qur'ān dikumpulkan pada masa Rasulullah oleh empat orang yang kesemuanya dari kaum Anshar, yaitu Ubay bin Ka'ab, Mu'ādh bin Jabal, Zaid bin Thābit, dan Abū Zaid. ${ }^{42}$ Karena kerja keras dan sentuhan tangan halus mereka, al-Qur'ān yang mulamula terhimpun dalam dada (sadr) mewujud dalam bentuk tulisan. Umat Islam pun sangat beruntung memiliki kesatuan dan keutuhan kitab suci yang kemurniannya dipelihara dengan tingkat kesungguhan yang luar biasa, hingga saat ini. ${ }^{43}$

Selain memerintah beberapa sahabat untuk menulis ayat-ayat al-Qur'ān, Nabi juga melibatkan berbagai pihak untuk mempercepat pengembangan pendidikan. Mereka yang memiliki keahlian baca-tulis diharuskan berpartisipasi memerangi buta aksara, laksana peran seorang ayah kepada anaknya. ${ }^{44}$ Bahkan hingga para tawanan perang Badar $(2 \mathrm{H})$ juga dimanfaatkan untuk mengurangi angka buta aksara. Tawanan perang yang menguasai baca-tulis tetapi tidak mampu menebus diri dengan sejumlah harta yang ditentukan, harus

${ }^{39}$ Al-Suyūṭ̂i, Al-Itqān, juz 1, 116. Baca juga al-Zarqānī, Manāhil al-'Irfān, jilid 1, 246.

${ }^{40}$ Perlu dipahami, masa ini merupakan masa peralihan, di mana tradisi baca-tulis yang sebelumnya tidak popular, asing, bahkan dipandang sebagai aib, oleh Nabi digalakkan dan difungsikan sebagai bagian dari kebutuhan dalam kehidupan sehari-hari. Karena itu, praktik tulis-menulis pada saat itu masih sangat sederhana. 'Ali al-Ṣābūni dalam al-Tibyān mengemukakan, pada saat-saat awal Islam, para sahabat melakukan penulisan al-Qur'ān pada pelepah kurma, kepingan batu, kulit dan daun kayu, tulang binatang, dan benda-benda lainnya. Cara ini ditempuh karena belum ada pabrik kertas di kalangan masyarakat Arab. Lihat Muhammad 'Ali al-Ṣābūni, al-Tibyān fî̀ 'Ulūm alQur'ān (Beirut: 'Ālam al-Kutub, cetakan pertama, 1985), 49.

${ }^{41}$ Șubhi al-Ṣālih, Mabāhith fì 'Ulūm al-Qur'ān, cetakan ke-17 (Beirut: Dār al-'Ilm li al-Maīäin, 1988), 69.

${ }^{42}$ Al-Zarkashì, al-Burhān fì 'Ulūm al-Qur'ān (Kairo: Dār al-Ḥadith, 2006), 170.

${ }^{43}$ Nurcholish Madjid (ed.), Khazanah Intelektual Islam (Jakarta: Bulan Bintang, 1984), 5.

${ }^{44}$ Al-‘Azami, Sejarah Teks Al-Qur'ān, 59. 
mengajarkan baca-tulis kepada sepuluh anak-anak muslim sebagai tebusan bagi kebebasan mereka. ${ }^{45}$ Ini semua menjadi bukti kesungguhan Nabi Muhammad s.a.w. mengatasi buta aksara dan mempercepat kemajuan dunia pendidikan.

Sejak itu, aktifitas membaca dan menulis dengan menggunakan huruf Arab (utamanya membaca dan menulis al-Qur'ān) mulai bergeliat dan disadari masyarakat Arab sebagai kebutuhan, setidaknya oleh kalangan pengikut setia Nabi Muhammad. ${ }^{46}$ Begitu juga dengan keberadaan al-Qur'ān-yang sudah tertulis dalam bentuk teks (mushaf al-Qur'ān) - telah menjadi inspirasi tersendiri bagi lahirnya sebuah peradaban keilmuan. ${ }^{47}$ Jelasnya, proses kodifikasi al-Qur'ān kemudian menjadi titik awal kebangkitan peradaban buku dalam dunia Islam.

Menurut Bernard Lewis, al-Qur'ān adalah literatur berbahasa Arab pertama dan terkaya di antara literatur-literatur yang ada. Pada permulaan abad kekuasaan Islam, sajak dan prosanya telah berkembang dengan baik. Ilmu pengetahuan dan pengajaran (teaching), pada awalnya, tumbuh dari kebutuhan untuk menginterpretasikan al-Qur'ān. Dari sini lahir ilmu hukum Islam dan sejarah Islam. Di sini, sejarah berkembang mulai dari biografi Nabi yang diperkaya dengan keterangan lisan yang historis mengenai tradisi Arab praIslam. Pada periode selanjutnya, orang-orang Arab sudah memiliki kesadaran sejarah yang tinggi dan segera menghasilkan berjilid-jilid buku sejarah dari berbagai jenis. Karya tentang sejarah Arab awal ditulis dalam bentuk ikhtisar hadis, berisi riwayat para saksi mata, yang disusun dalam rangkaian nama para perawi. Dari sanalah laporan (interpretasi) sejarah dikembangkan. Maka, lahirlah Kutub al-Sīrah wa al-Tärikh karya Ibn Hishām (m. 218) dan Tärikh alTabari karya al-Ṭabari (225-310 H/839-923 M). Dan sebagai puncaknya, lahir Muqaddimah $^{48}$ karya Ibn Khaldūn (732-808 H/1332-1406 M), ahli sejarah bangsa Arab sekaligus pemikir tentang sejarah terbesar di Abad Tengah. ${ }^{49}$

Pendapat yang sama disampaikan oleh A'z̧ami . Menurutnya, tidak ada sumber yang mencatat adanya buku berbahasa Arab di Semenanjung Arabia

\footnotetext{
${ }^{45}$ Kebijakan Muhammad ini merupakan langkah cerdas. Bekas bala tentara Quraish yang kalah perang itu tidak dibiarkan kembali ke induknya dan menjadi musuh Islam yang berbahaya, juga tidak dibunuh/ mati sia-sia. Dengan pertimbangan matang dan atas dasar rasa kemanusiaan, mereka dipekerjakan sebagai pengajar. Kemampuan mereka dalam hal baca-tulis diberdayakan, sekali lagi, untuk kemakmuran umat dalam jangka panjang. Baca Hasan, Sejarah dan Kebudayaan Islam, 118.

${ }^{46}$ Minat terhadap tradisi baca-tulis tumbuh sebanding dengan minat baru dalam teks al-Qur'ān sebagai pembimbing untuk semua pemikiran dan aktivitas, dan keinginan untuk menjaganya dan menyampaikannya secara akurat. Baca al-Faruqi, The Cultural Atlas of Islam, hlm, 358.

${ }^{47} \mathrm{Hitti}$, History of the Arabs, 127.

${ }^{48}$ Ibn Khaldūn, Muqaddimah, 417.

${ }^{49}$ Lewis, The Arabs in History, 137.
} 
sebelum Islam muncul. Al-Qur'ān adalah buku pertama berbahasa Arab. Segera setelah tiba di Madinah Rasulullah mengatur sistem pendidikan dengan melibatkan orang-orang yang berilmu, meskipun masih minim. Pada masa berikutnya (kepemimpinan al-Khulafă' al-Rāshidūn), sejarah mencatat, Madinah berfungsi sebagai pusat agama, militer, ekonomi, dan administrasi negara-yang pengaruhnya menembus dari Afganistan ke Tunisia, Turki selatan hingga Yaman, dan Muscat hingga Mesir. ${ }^{50}$

Dalam konteks ini, posisi al-Qur'ān tidak terbatas sebagai kitab suci yang memerintahkan masyarakat (user)-nya untuk berbudaya baca-tulis. Lebih dari itu, proses keberadaan al-Qur'ān - mulai dari fase penerimaan wahyu oleh Nabi dari Allah s.w.t. melalui perantara Jibril, turunnya ayat demi ayat, penghafalan dan penulisan yang dilakukan para sahabat pada masa Nabi dan atas perintah Nabi sendiri, pengumpulan benda-benda yang bertuliskan ayat alQur'ān, kodifikasi yang dilakukan mulai dari masa kekhalifahan Abu Bakar yang ditindaklanjuti khalifah sesudahnya, sampai lahirnya mushaf standar yang dipelopori Khalifah Uthmān (memerintah 644-656 M), dan akhirnya muncul alQur'ān berbentuk tulisan dan berjilid (mushaf) dengan segala kekayaan bentuk fisik, cetakan, ornamen, dan iluminasi seperti yang bisa kita jumpai hari inimerupakan inspirasi dan motivasi luar biasa bagi lahirnya budaya literasi Arab. ${ }^{51}$

Sampai di sini, masyarakat Arab (Islam) telah memiliki kesadaran mencatat peristiwa-peristiwa penting. Tradisi masyarakat Arab yang satu ini begitu maju, dan bahkan mengungguli bangsa-bangsa lain di sekitarnya. Dari sini muncul kesadaran baru, yaitu keinginan untuk menyerap pengetahuan dari bangsa-bangsa lain. Sebuah ambisi pengembaraan intelektual lintas kawasan dan ideologi. Langkah yang diambil para intelektual muslim, saat itu, adalah menerjemahkan karya ilmuwan Yunani kuno ke dalam bahasa Arab. ${ }^{52}$

Gerakan penerjemahan dimulai pada masa kekuasaan Bani Umayyah di Damaskus. Pada masa ini sejumlah karya ilmuwan Yunani dan Koptic tentang ilmu kimia diterjemahkan. Di bawah kekuasaan Umar II (717-720), Masarjawaih, seorang Yahudi dari Basra menerjemahkan buku kedokteran dari bahasa Siria ke dalam bahasa Arab. Buku lain yang diterjemahkan dari bahasa Yunani ke dalam bahasa Siria dan/atau Arab adalah tentang astronomi, fisika, dan matematika. Khalifah juga mengirim sarjana-sarjana ke berbagai tempat, termasuk ke Byzantium, untuk mencari manuskrip-manuskrip. Beberapa orang dari masa awal penerjemahan juga menghasilkan karya buku (bukan terjemahan)

\footnotetext{
${ }^{50} \mathrm{Al}-\mathrm{A}$ ‘ẓami, Sejarah Teks Al-Qur'ān, 184.

${ }^{51}$ Al-Faruqi, The Cultural Atlas of Islam, 34.

${ }^{52}$ Amin Abdullah, "Penerjemahan Karya Klasik" dalam Ensiklopedi Tematis Dunia Islam, Pemikiran dan Peradaban, 15.
} 
berisi ikhtisar atau interpretasi buku-buku Yunani. Namun tidak lama kemudian lahir generasi penulis muslim orisinil, terutama dari bangsa non-Arab, seperti: sejarahwan dan teolog al-Ṭabari (m. 310 H/923 M), ahli fisika al-Rāzí (865925), dokter dan filsuf Ibn Sīnā (980-1037), serta astronom dan ilmuawan ensiklopedik al-Bīrūni $(970-1048){ }^{53}$

Gerakan penerjemahan khazanah intelektual Yunani itu mencapai puncaknya pada masa kekhalifahan al-Ma'mun (memerintah 198-219 H/ 813$833 \mathrm{M}$ ) di Baghdad yang menganut faham Mu'tazilah. Faham Mu'tazilah telah membuat raja ini "liberal" dalam memposisikan ilmu pengetahuan rasional. Inisiatifnya mendirikan Bait al-Hikmah sebagai pusat kegiatan ilmiah telah menciptakan suasana kondusif di kalangan muslim tertentu untuk berkembangnya pemikiran spekulatif. ${ }^{54}$

Penting untuk digarisbawahi, pada periode ini, setidaknya ada tiga prestasi yang dicapai generasi muslim. Pertama, para intelektual muslim berhasil menyerap khazanah keilmuan bangsa lain dan menyajikan kepada masyarakat dalam bentuk buku berbahasa Arab. ${ }^{55}$ Ini adalah upaya penting dalam rangka mempermudah akses keilmuan bagi masyarakat muslim (Arab). Kalau sebelumnya khazanah intelektual yang ditulis dengan bahasa Yunani hanya bisa diakses masyarakat Yunani, maka setelah terjemahan bahasa Arabnya terbit, komunitas Arab bisa menyerap informasi yang lahir dari negeri itu. Kedua, generasi muslim sudah mampu menuliskan informasi yang diperoleh dari buku-buku asing meskipun dalam bentuk ikhtisar. ${ }^{56}$ Tahap ini selangkah lebih maju ketimbang sekedar menerjemahkan. Ketiga, lahirnya generasi penulis muslim, seperti al-Rāzì (864-925), Ibn Sīnā (980-1037) dan al-Bīrūnì (9731048). ${ }^{57}$ Bukankah ini petanda awal, bahwa mulai terjadi proses hegemoni ilmu pengetahuan oleh kaum intelektual muslim.

Nurcholish Madjid menambahkan, karena ketertarikan umat Islam yang begitu tinggi terhadap para filsuf Yunani, terdapat satu buku filsafat yang menafsirkan pemikiran-pemikiran Aristoteles-filsuf yang oleh orang Islam dipandang sebagai al-Mu'allim al-AwWal (guru pertama), kini aslinya hanya diketahui dalam bahasa Arab, Fi al-Khair al-Mahḍ. Bahkan ada dugaan bahwa

${ }^{53}$ Lewis, The Arabs in History, 137-138. Pada masa keemasan peradaban Islam itu, bahasa Arab merupakan bahasa perantara di wilayah kekuasaan Islam yang luas dan merupakan bahasa universal ilmiah (bahasa ilmu pengetahuan). Lihat juga Issa J. Boullata, "Arabic" dalam John L. Esposito (editor in chief), The Oxford Encyclopedia of the Modern Islamic World, Vol. I (New York: Oxford University Press, 1995), 96.

${ }^{54}$ Madjid (ed.), Khazanah Intelektual Islam, 23.

${ }^{55}$ Lihat Amin Abdullah, "Penerjemahan Karya Klasik" dalam Ensiklopedi Tematis Dunia Islam, Pemikiran dan Peradaban, 15.

${ }^{56}$ Lewis, The Arabs in History, 137.

${ }^{57}$ Boullata, "Arabic" dalam Esposito (editor in chief), The Oxford Encyclopedia of the Modern Islamic World, 96. 
yang mengarangnya adalah orang Islam sendiri, kalau bukan orang Yahudi atau Kristen yang berbahasa Arab. Kelak, buku ini kemudian diterjemahkan ke bahasa Latin dengan judul Liber de Causis. Ini menunjukkan bahwa pada era itu literasi Arab sudah menjadi pintu gerbang bagi tradisi dan khazanah keilmuan tertentu. Masyarakat Latin pun harus menerjemahkan buku-buku filsafat dari buku-buku karya ilmuwan Arab (Islam). ${ }^{58}$

Kelak, sejarah mencatat, bangsa Arab berhasil menjadi pewaris tunggal bagi berbagai budaya dan tradisi panjang sejak zaman Yunani-Romawi, Iran, Fir'aun, dan Assyria-Babilonia. Philip K. Hitti menggambarkan ghirah intelektual masyarakat Arab yang membara. Hitti menulis, dengan berbekal rasa ingin tahu yang kuat dan potensi tersembunyi yang tidak pernah muncul sebelumnya, orang-orang Arab muslim mulai berasimilasi, mengadaptasi dan menghasilkan khazanah intelektual dan estetikanya sendiri. Di Ctesiphon, Edessa, Nisibis, Damaskus, Yerusalem, dan Iskandariyah, mereka menyaksikan, mengagumi dan meniru karya-karya para arsitek, seniman, perajin, dan pengusaha intan. Ke pusat-pusat peradaban kuno inilah mereka datang, melihat, dan menang. ${ }^{59}$

Perlu dicatat, lahirnya tradisi dan peradaban ilmu pengetahuan dalam dunia Islam bermula dari turunnya al-Qur'ān sebagai penggeraknya. Dalam perjalanannya, terjadi transformasi ilmu pengetahuan dari Yunani ke Persia, dan dari Persia kemudian ke dunia Arab Islam. Dengan demikian, realitas menunjukkan bahwa antara sebelum dan sesudah al-Qur'ān diturunkan terdapat perbedaan yang jelas berkaitan dengan perkembangan tradisi literasi Arab. Sebelum al-Qur'ān lahir, tradisi baca-tulis Arab tidak mengalami perkembangan yang berarti, namun setelah kitab suci ini turun, tradisi baca-tulis Arab berkembang pesat. Al-Qur'ān telah berperan sebagai inspirator/motivator masyarakat Arab untuk berbudaya baca-tulis. Bermula dari kebutuhan menuliskan wahyu dan menjalankan perintah agama, masyarakat Arab (Islam) kemudian memiliki tradisi menuliskan peristiwa-peristiwa yang mereka alami. Pasca turunnya al-Qur'ān, banyak keilmuan Arab yang dibukukan. Seperti ilmuilmu keagamaan, hukum, kedokteran, filsafat, sejarah dan lain sebagainya.

Berawal dari kebutuhan mempelajari al-Qur'ān pula, sistem tulisan (paleography) Arab, terutama dalam masalah nuqat (نق titik) di sempurnakan. Berbeda dari sebelumnya, pada masa awal setelah turunnya al-Qur'ān, nuqat mempunyai dua makna, yaitu nuqat al-i jām ${ }^{60}$ ( نقطالاعجام: kerangka tanda titik)

${ }^{58}$ Madjid (ed.), Khazanah Intelektual Islam, 24.

${ }^{59} \mathrm{Hitti}$, History of the Arabs, 175.

${ }^{60}$ Tanda titik (yang terletak di atas atau di bawah) guna membedakan huruf lain yang kerangkanya sama, seperti $j(ج), h(\tau), k h(\dot{\zeta})$. Sistem ini sudah terkenal pada zaman Arab sebelum Islam atau setidaknya pada awal Islam sebelum mushaf Uthmani. 
dan nuqat al-i 'rāb ${ }^{61}$ ( نقطالاعر اب: tanda diakritikal). Dari kebutuhan mempelajari al-Qur'ān juga telah menginspirasi para pemerhati bahasa Arab (pada masa kepemimpinan Umar) untuk membakukan tata bahasa Arab (grammar) dengan ditulisnya disiplin ilmu naḥ..$^{62}$ Disebutkan dalam The Cultural Atlas of Islam, banyaknya orang-orang non-Arab yang masuk Islam kemudian mempelajari bahasa Arab dengan sungguh-sungguh dan akhirnya memberi sumbangan besar untuk tata bahasa, sintaks, leksikografi, dan kritikisme sastra Arab adalah karena ingin menangkap pesan dan keindahan al-Qur'ān. ${ }^{63}$

Dengan demikian, al-Qur'ān dan usaha keras Nabi Muhammad telah mendorong pesatnya perkembangan tradisi literasi Arab. Dalam konteks ini, literasi Arab dimaknai sebagai alat komunikasi ide dan ilmu pengetahuan yang berfungsi sebagai sistem untuk mempertahankan kahazanah budaya dan keilmuan Arab. Sehingga, berawal dari gerakan baca-tulis pada komunitas Arab yang dikomandani Nabi, membawa implikasi kepada lahirnya tradisi intelektual dari komunitas Arab. Di lain pihak, pembahasan literasi Arab kurang mendapat perhatian dalam disiplin ulumul Qur'ān. ${ }^{64}$ Kondisi ini perlu dikritisi, karena sedari awal peran literasi Arab begitu urgen terhadap proses lahirnya peradaban Arab (Islam) yang agung. Akhirnya, seluruh uraian di atas cukup menjadi latar belakang dan landasan untuk lebih jauh mengkaji tentang al-Qur'ān dan pengaruhnya terhadap literasi Arab, sebagaimana menjadi tema pokok dalam penelitian ini.n, teratur dan positif). Sebaliknya, bangsa yang masyarakatnya tidak memiliki tradisi baca-tulis tidak akan pernah menjadi bangsa yang maju, berperadaban, dan berdaulat di kancah internasional. ${ }^{65}$ Apabila kita merujuk

${ }^{61}$ Dalam bahasa Arab disebut tashkil (تشكيل: seperti d̦ammah, fathah, kasrah) atau disebut juga al-harakah. Sistem tanda ini dirumuskan oleh Abu al-Aswad al-Du'ali (10 sebelum Hijrah-69 H/611-688 M) sekitar tahun 20 H/640 M. Lihat Abū 'Amr al-Dāni, alMuhkam fí Naqt al-Masāhạif (Damaskus, 1379/1960), 6. Baca juga al-A'ẓamí, Sejarah Teks Al-Qur'ān, 151. Lihat juga Ma'rifat, Sejarah al-Qur'ān, 175.

${ }^{62}$ Banyaknya kasus kesalahan dalam mempelajari al-Qur'ān pada masa awal Islam menyebabkan Umar prihatin dan meminta Abu al-Aswad al-Du'ali untuk mengarang sebuah risalah tentang tata bahasa Arab. Lihat al-Dāni, al-Muḥkam fī Naqt al-Mașāhif, 4. Baca juga al-A'z̧ami, Sejarah Teks Al-Qur'ān, 154.

${ }^{63}$ Al-Faruqi, The Cultural Atlas of Islam, 105.

${ }^{64}$ Ulumul Qur'ān adalah kajian yang berhubungan dengan Al-Qur'ān dari sisi turun (nuzūi) pengumpulan (jam ), penertiban (tartī $)$, pembukuan (tadwin), mengetahui sebab turun (sabāb nuzūi), makkì dan madanì, nāsikh mansūkh, muhkām mutashābihăt, dan kajian lain yang terkait dengan Al-Qur'ān. Buku rujukan ulumul Qur'ān paling otoritatif adalah al-Burhān fí 'Ulüm al-Qur'ān yang ditulis oleh al-Zarkashì. Buku ini hingga sekarang masih dikagumi para ahli ulumul Qur'ān. Lihat Komentar Abu al-Faḍl Ibrahim, dalam pengantar muhaqqiq untuk al-Suyūtị, al-Itqān, juz 1, 6.

${ }^{65}$ Rokhmin Dahuri, "Budaya Baca dan Kemajuan Bangsa", Republika (Sabtu, 22/3/2008). Baca juga Ki Supriyoko, "Mengatasi Buta Aksara Dunia", Kompas (Senin, 24/3/2008). Lihat pula Dhipuri PS, "Melongok Budaya Baca dan Tulis Masyarakat 
kembali kepada al-Qur'ān, kita akan menemukan, bahwa kitab suci umat Islam ini sejak semula menyerukan kepada manusia untuk membaca, menulis dan mempelajari ilmu pengetahuan (QS. al-'Alaq/96: 1-5). Adalah kenyataan bahwa sebelum akhirnya Islam menampakkan dirinya sebagai satu peradaban adiluhung $^{66}$ - kombinasi dari sikap pasrah, penyembahan dan tradisi ilmu pengetahuan ${ }^{67}$ - doktrin pertama yang ditanamkan kepada para pemeluknya adalah supaya umat manusia sekalian berbudaya baca-tulis.

\section{Lahirnya Ilmu-ilmu Keislaman}

Sejarah mencatat, hampir tujuh abad lamanya, mulai 750 hingga $1500 \mathrm{M}$ atau hingga $700 \mathrm{H}$, Islam mulai menapaki sejarah dan berhasil mencapai masa kejayaan baik dalam politik, ekonomi dan juga dalam peradaban dan ilmu pengetahuan. ${ }^{68}$ Pada waktu itu, (sejak lahirnya Islam hingga kejatuhan Granada di Spanyol) peradaban Islam memberi kontribusi yang besar kepada kemajuan dunia. Dalam rentang waktu itu, lahir ratusan ilmuwan muslim yang mencetuskan beragam teori, yang kelak mengilhami kemunculan renaissance di Eropa. ${ }^{69}$ Di antara sederet nama ilmuan muslim yang mendunia adalah Jābir Ibn Hayyān (721-815 ahli ilmu kimia, Ibn Khaldūn (732-808 H/1332-1406 M) pakar sosiologi dan sejarah, al-Khawārizmi (780-850) ahli matematika, al-Rāzì (864-

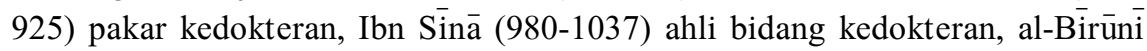
(973-1048) pakar bidang fisika, Ibn Bațūtah (m. 1377) ${ }^{70}$ seorang antropolog dan pelancong (traveler), dan masih banyak lagi yang lainnya. ${ }^{71}$ Mereka semua adalah putera-putera terbaik dari generasi muslim yang telah menyumbangkan tenaga dan fikirannya untuk kemajuan dunia intelektual Islam.

Sumbangan Islam di bidang ilmu pengetahuan dan teknologi ini sangat besar artinya bagi kemajuan dan kemaslahatan dunia. Bagaimana tidak, alKhawārizmi (780-850), misalnya, menemukan angka nol (0)_yang pada zaman sebelumnya (Cina, India, maupun Yunani) belum diketahui. Uraian beragam teori sosiologi dan sejarah yang dikemukakan Ibn Khaldūn (1332-1406) dalam karya monumentalnya, Muqaddimah sampai sekarang tetap aktual dan menjadi

Jepang" dalam http://www.rumahdunia.net/ (diakses 8/5/2008). Lihat juga "Kadar Literasi: Perbandingan Antarabangsa" dalam http://i-baca.pnm.my/ (diakses 8/5/2008).

${ }^{66} \mathrm{Hitti}$, History of the Arabs, 3-7.

${ }^{67}$ Bandingkan dengan al-Faruqi, The Cultural Atlas of Islam, 76.

${ }^{68} \mathrm{Hitti}$, History of the Arabs, 4.

${ }^{69}$ Nurcholish Madjid, "Kata Pengantar", dalam Bernard Lewis, Bangsa Arab dalam Lintasan Sejarah, terj. Said Jamhuri (Jakarta: Pedoman Ilmu Jaya, 1994) vi-x.

${ }^{70}$ Baca Asmā' Abū Bakar Muhammad, Ibn Bațtụtah: al-Rajul wa al-Rị̣lah (Beirut: Dār al-Kutub al-'Ilmiyah, 1992).

${ }^{71}$ S.I. Poeradisastra, Sumbangan Islam kepada Ilmu dan Peradaban Modern (Jakarta: P3M, 2006), 10 
referensi sosiologi modern. Belum lagi berbagai teori kedokteran yang dikemukakan al-Rāzi (864-925) tentang penyakit cacar, serta Ibn Sīnā (9801037) tentang pembiusan dan pembedahan. ${ }^{72}$ Semua kontribusi para intelektual muslim ini masih bisa dinikmati dan memberi kemudahan bagi orang banyak hingga pada masa modern sekarang ini.

Upaya generasi muslim awal dalam mendesain ilmu-ilmu keislaman (tradisional) dilakukan bermula dari kebutuhan untuk memahami wahyu (alQur'ān), selain juga didorong oleh sikap mengimaninya sebagai satu-satunya kebenaran. Setidaknya ada tujuh keilmuan yang mulai dirintis oleh para intelektual muslim generasi awal hingga tābi'in, yaitu: Pertama, kodifikasi huruf Arab. Kedua, penggunaan titik dan shakl dalam sistem tulisan Arab. Ketiga, pembakuan tata bahasa Arab (nahwu). Keempat, penulisan ilmu-ilmu al-Qur'ān (ulumul Qur'ān). Kelima, penulisan tafsir al-Qur'ān. Keenam, penulisan hadis-hadis Nabi Muhammad s.a.w. dan ketujuh, penulisan sejarah (sirah). Berdasarkan penelusuran penulis, tujuh disiplin ilmu ini terkodifikasi karena kebutuhan untuk memahami pesan dan kandungan al-Qur'ān, selain juga motivasi dari al-Qur'ān itu sendiri, agar umat Islam bersedia membaca, mengkaji dan menciptakan peradaban yang terbaik di muka bumi ini.

Penulis sengaja memilah-milah ketujuh disiplin ilmu di atas dan mengklaim sebagai ilmu yang terkodifikasi karena kebutuhan untuk memahami pesan dan kandungan al-Qur'ān, meskipun dalam tradisi kajian ulumul Qur'ān klasik (seperti terdapat dalam al-Burhān, al-Itqān, dan lain-lain), sejarah huruf Arab, munculnya titik dan shakl dalam sistem tulisan Arab, pembakuan tata bahasa Arab (nahwu), serta kodifikasi tafsir terangkum dalam kajian ilmu-ilmu al-Qur'ān; sementara sirah dikelompokkan dengan kajian hadis Nabi Muhammad s.a.w. Hal ini penulis lakukan dengan tujuan untuk memberi perhatian lebih pada ketujuh bidang tersebut.

${ }^{72}$ Lewis, The Arabs in History, 137-138. Pada masa keemasan peradaban Islam itu, bahasa Arab merupakan bahasa perantara di wilayah kekuasaan Islam yang luas dan merupakan bahasa universal ilmiah (bahasa ilmu pengetahuan). Lihat juga Issa J. Boullata, "Arabic" dalam John L. Esposito (editor in chief), The Oxford Encyclopedia of the Modern Islamic World, 96. 
Daftar Literature Keislaman

versi Ibn Nadim (m. $380 \mathrm{H}$ ) dalam al-Fihrist

\begin{tabular}{|c|c|c|c|}
\hline No. & Kategori Kitab & Jumlah & Keterangan \\
\hline 1. & Kajian tafsir al-Qur'ān & \pm 46 judul & Terdiri tafsir al-Qur'ān. \\
\hline 2. & Kajian Ulumul Qur'ān & \pm 182 judul & 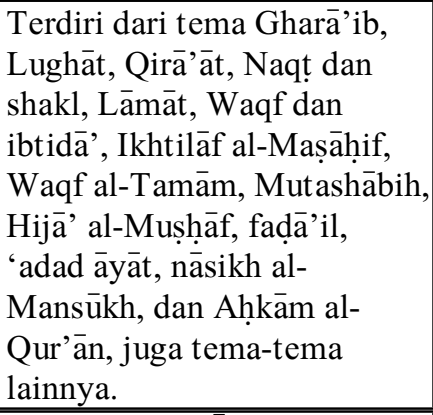 \\
\hline 3. & Kajian Sirah Nabi s.a.w. & \pm 26 judul & Akhbār al-Nabì. \\
\hline
\end{tabular}

Daftar literature Keislaman menurut

Hāaji Khalifah (1017-1067 M), dalam Kashf al-Zunūn

\begin{tabular}{|c|l|c|l|}
\hline No. & \multicolumn{1}{|c|}{ Kategori Kitab } & Jumlah & \multicolumn{1}{|c|}{ Keterangan } \\
\hline 1 & Kajian al-Qur'ān & +348 judul & $\begin{array}{l}\text { Terdiri dari ulumul Qur'ān, } \\
\text { ulumut Tafsir, dan tafsir. } \\
\text { Sebanyak 288 kitab } \\
\text { menggunakan kata 'tafsir' } \\
\text { sebagai judul. }\end{array}$ \\
\hline 2 & Kajian Hadis & +67 judul & $\begin{array}{l}\text { Terdiri dari kitab kumpulan } \\
\text { hadis dan ilmu hadis. }\end{array}$ \\
\hline 3 & Kajian Sirah & \pm 52 judul & $\begin{array}{l}\text { Sejarah Nabi, para sahabat, } \\
\text { hingga sosial masyarakat. }\end{array}$ \\
\hline 4 & Nahwu & \pm 80 judul & Tema-tema tata bahasa Arab. \\
\hline
\end{tabular}

Keterangan: Daftar terbitan literatur keislaman yang berhasil dihimpun oleh Ibn Nadìm dan Häji Khalifah ini setidaknya memberi gambar perkembangan ilmu keislaman pada saat itu.

\section{Penutup}

Tradisi literasi atau baca-tulis pada masa setelah lahirnya Islam menggantikan tradisi lisan (oral) dan hafalan yang sangat populer dan bahkan dibanggakan oleh orang-orang Arab kala itu. Al-Qur'ān melalui unit wahyu pertamanya (QS. al-'Alaq/96:1-5), menawarkan tradisi selain oral dan hafalan, yaitu membaca dan menulis. Dengan berbudaya baca-tulis akan memungkinkan seseorang untuk bisa mengakses (menjangkau) informasi yang lebih luas dan 
mendalam, selain juga bisa membantu mengutarakan maksud seseorang dengan lebih detail. Namun demikian, bukan berarti tradisi lisan dan hafalan tidak berguna sama sekali. Dalam kondisi tertentu, sistem orang dan hafalan tetap diperlukan dan memiliki keunggulan dan sifat praktis tersendiri.

Tulisan ini bermaksud menjawab apa yang mempengaruhi pesatnya perkembangan peradaban ilmu pengetahuan keislaman. Berdasarkan penelusuran data-data sejarah, faktor yang mempercepat perkembangan peradaban ilmu pengetahuan keislaman adalah turunnya al-Qur'ān, serta beragam kebutuhan umat Islam untuk mempelajari kandungan pesan al-Qur'ān. Kebutuhan untuk mencatat wahyu sehingga al-Qur'ān terdokumentasi dalam wujud lembaran kertas (mushaf), ghirah dan dedikasi yang amat tinggi dari umat Islam untuk mempelajari al-Qur'ān, serta tindakan nyata Nabi Muhammad s.a.w. dalam mempelopori gerakan baca-tulis telah menjadi media dan momentum yang sangat tepat bagi perkembangan tradisi intelektual kaum muslim. Berkat tuntunan wahyu, kerja keras Nabi sebagai interpretasi dan pengejawantah wahyu, di tengah-tengah umat muslim telah terjadi 'kompetisi' dalam mendalami ilmu pengetahuan. Tentu saja, ilmu pengetahuan keislaman saat itu masih dalam pengertian yang terbatas.

Tulisan ini juga menjelaskan lahirnya ilmu-ilmu keislaman diawali dengan usaha keras Nabi s.a.w. dalam memerangi illiteracy (buta aksara) dan menggantikannya dengan tradisi literasi. Memang sebelum turunnya al-Qur'ān tradisi literasi sudah berlaku di lingkungan masyarakat Arab, tetapi masih dalam lingkup yang sangat terbatas, dan hanya sebagian kecil saja masyarakat Arab yang berbudaya baca-tulis. Di sini, tradisi literasi Arab tidak berkembang hingga dalam waktu yang cukup lama. Al-Qur'ān-melalui motivasi, perumpamaan (tamthi $\overline{1}$ ), serta perintah baca-tulis-dan kerja keras Nabi Muhammad s.a.w. berperan penting dalam mempopulerkan tradisi literasi Arab. Karena al-Qur'ān juga, sistem tulisan Arab menjadi sempurna. Indikatornya adalah: terjadikan kodivikasi jumlah dan bentuk huruf (abjad) Arab, penyempurnaan sistem huruf Arab dengan digunakannya syakl/nuqtah, dan dibukukannya ilmu nahwu.

Sejak saat itu, tidak hanya shakl, nuqtah, dan nahwu yang menjadi perbincangan hangat di tengah-tengah masyarakat intelektual muslim, tetapi juga muncul kesadaran baru dan semangat mempelajari ilmu pengetahuan (wahyu). Maka, bisa kita saksikan, bermunculan disiplin ilmu baru dalam dunia keislaman awal, misalnya, kesadaran mempelajari dan membukukan ilmu-ilmu al-Qur'ān ( 'ul'um al Qur'ān), ilmu tafsir ( 'ulüm al-tafsiri), penulisan kitab tafsir, dan lain-lain. Kemajuan tradisi literasi Arab pada masa setelah turunnya alQur'ān juga bisa dilihat dari populernya kebiasaan menuliskan hadis-hadis Nabi, 
Sirah Nabi, penerjemahan buku-buku karya para filsuf Yunani, dan lahirnya generasi pemikir dan penulis produktif dari kalangan Muslim.

Menurut hemat penulis, kesuksesan dunia Islam bisa terulang kembali kalau kita mentradisikan membaca-menulis (tradisi literasi). Dengan tradisi literasi, memungkinkan kita untuk menganalisis satu tema tertentu secara mendalam. Wallāh a lam bi al-ṣawāb.

\section{Daftar Pustaka}

Al-A'zamī, Muhammad Mustafa. Sejarah Teks Al-Qur'ān. Terj. Sohirin Solihin, dkk. Jakarta: Gema Insani Press, 2005.

Abdullah, M. Amin. "Penerjemahan Karya Klasik." Dalam Ensiklopedi Tematis Dunia Islam, Pemikiran dan Peradaban. Jakarta: Ichtiar Baru van Hoeve, 2002.

Amal, Taufik Adnan. Rekonstruksi Sejarah Al-Qur'ān. Jakarta: Pustaka Alvabet, 2005.

Al-Ba'labakkī, Munīr. Al-Mawrid: Qāmūs Ingelizī-'Arabī. Beirut: Dār al-'Ilm lil Malāyin, 1977.

Boullata, Issa J. “Arabic.” Dalam John L. Esposito. Editor in chief. The Oxford Encyclopedia of the Modern Islamic World. Vol. I. New York: Oxford University Press, 1995.

Al-Bukhāri. Al-Jāmi` al-Saḥịh al-Mukhtasar. Cetakan ketiga, juz 2. Beirut: Dār Ibn Kathīr al-Yamāmah, 1987.

Dahuri, Rokhmin. "Budaya Baca dan Kemajuan Bangsa." Republika (Sabtu, 22/3/2008).

Dhipuri PS. "Melongok Budaya Baca dan Tulis Masyarakat Jepang." Dalam http://www.rumahdunia.net/ diakses 8/5/2008).

Al-Faruqi, Isma'il R. dan Lois Lamya' al-Faruqi. The Cultural Atlas of Islam. New York: Macmillan Publishing Company, 1986.

Hasan, Hasan Ibrahim. Sejarah dan Kebudayaan Islam. Terj. A. Bahauddin. Jakarta: Kalam Mulia, 2006.

Hitti, Philip K. History of the Arabs. London: Macmillan Education, 1970. Tenth edition.

Ibn Khaldūn. Muqaddimah. Kairo: Dār al-Fikr, t.th.

Al-Khafajī, Muhammad 'Abd al-Mun'im. al-Shi'r al-Jāhilī. Beirut: Dar alKitāb,1973.

Ki Supriyoko. "Mengatasi Buta Aksara Dunia.” Kompas (Senin, 24/3/2008).

Lewis, Bernard. The Arabs in History, cet. $1^{\text {st, }}$ New York: Harper Torchbooks, 1960. 
Madjid, Nurcholish. "Kata Pengantar." Dalam Bernard Lewis. Bangsa Arab dalam Lintasan Sejarah. Terj. Said Jamhuri. Jakarta: Pedoman Ilmu Jaya, 1994.

Ma‘rifat, Muhammad Hadi. Sejarah Al-Qur'ān. Jakarta: Al-Huda, 2007.

Mir, Mustansir. “The Qur'ān in Muslim Thought and Practice.” Dalam John L. Esposito Editor in chief. The Oxford Encyclopedia of the Modern Islamic World. Vol. 3. New York: Oxford University Press, 1995.

Pedersen, J. Fajar Intelektualisme Islam. Terj. Alwiyah Abdurrahman. Cetakan pertama. Bandung: Mizan, 1996.

Poeradisastra, S.I. Sumbangan Islam kepada Ilmu dan Peradaban Modern. Jakarta: P3M, 2006.

Al-Qaț̣̄ān, Mannā' Khalìl. Mabāhith fī 'Ulūm al-Qur'ān. Mekah: Maktabah alMa'ārif, 1988.

Al-Qurțubī. Al-Jāmi ' li Aḥkām al-Qur’ān. Jilid 10. Beirut: Dār al-Kutub al'Ilmiyah, 1993.

R, Ilham Khoiri. Al-Qur'ān dan Kaligrafi Arab. Jakarta: Logos, 1999.

Romdhoni, Ali. “Al-Qur'ān dan Masyarakat Pembaca.” Surat Kabar Mahasiswa Amanat, IAIN Walisongo Semarang, (109 Agustus-September 2007)

Rosenthal, F. "Significant Uses of Arabic Writing." Dalam R. Ettinghausen dan O. Kurz. Eds. Four Essays on Art and Literature in Islam. Vol. 2. Leiden: E. J. Brill, 1971.

Al-Ṣābūnī, Muhammad 'Ali. Al-Tibyān fì 'Ulūm al-Qur'ān. Beirut: ‘'Ālam alKutub, cetakan pertama, 1985.

Al-Ṣālih, Șubhị. Mabāhith fī 'Ulūm al-Qur'ān. Cetakan ke-17. Beirut: Dār al'Ilm li al-Malāyin, 1988.

Shahrur, Muhammad. Al-Kitāb wa al-Qur'ān, Qirā’ah Mu'āṣirah. Kairo: Sina li al-Nashr, 1992.

Sherif, Faruq. Al-Qur'ān Menurut al-Qur'ān. Terj. M. H. Assagaf dan Nur Hidayah. Jakarta: PT. Serambi Ilmu Semesta, 2001.

Shihab, M. Quraish. Membumikan Al-Qur'ān: Fungsi dan Peran Wahyu dalam Kehidupan Masyarakat. Bandung: Mizan, 1999.

------. Mukjizat Al-Qur'ān. Bandung: Mizan, 1998.

Spencer, Jean E. "Literacy." Dalam The Encyclopedia Americana International Edition. Vol. 17. New York: Americana Corporation, 1972.

Al-Suyūtị. Al-Itqān fī 'Ulūm al-Qur'ān. Juz 1. Beirut: Dār al-Kutub al'Ilmiyah, 2000.

Al-Ṭabarì. Jämi al-Bayān fī Ta’wìl al-Qurān. Cetakan pertama. Juz 24. Mu'assasah al-Risālah, 2000.

Teeuw, A. Indonesia: Antara Kelisanan dan Keberaksaraan. Jakarta: Pustaka Jaya, 1994.

Al-Zarkashī. Al-Burhān fī 'Ulūm al-Qur'ān. Kairo: Dār al-Hadith, 2006. 
Ali Romdhoni

Al-Zarqānī. Manāhil al- 'Irfān fī 'Ulūm al-Qur'ān. Jilid 1. Beirut: Dār al-Kutub al-'Ilmiyah, 1996.

Zuhri, Muh. Potret Keteladanan Kiprah Politik Muhammad Rasulullah. Yogyakarta: LESFI, 2004.

"Kadar Literasi: Perbandingan Antarabangsa." Dalam http://i-baca.pnm.my/ (diakses 8/5/2008). 